Article

\title{
Synthesis, Crystal Structure, Thermal Analysis, and DFT Calculations of Molecular Copper(II) Chloride Complexes with Bitopic Ligand 1,1,2,2-tetrakis(pyrazol-1-yl)ethane
}

\author{
Elizaveta Lider ${ }^{1,2}{ }^{1}$, Taisiya Sukhikh ${ }^{1,2}{ }^{\oplus}$, Anton Smolentsev ${ }^{1}$, Evgeny Semitut ${ }^{1}$, \\ Evgeny Filatov ${ }^{1,2}$ and Andrei Potapov $1,3, *$ (i) \\ 1 Nikolaev Institute of Inorganic Chemistry, Siberian Branch of the Russian Academy of Sciences, 3 Lavrentiev \\ Ave., 630090 Novosibirsk, Russia; lisalider@ngs.ru (E.L.); sukhikh@niic.nsc.ru (T.S.); \\ smolentsev@ngs.ru (A.S.); semitut@ngs.ru (E.S.); decan@niic.nsc.ru (E.F.) \\ 2 Department of Natural Sciences, Novosibirsk State University, 2 Pirogova Str., 630090 Novosibirsk, Russia \\ 3 Kizhner Research Center, National Research Tomsk Polytechnic University, 30 Lenin Ave., \\ 634050 Tomsk, Russia \\ * Correspondence: potapov@niic.nsc.ru
}

Received: 29 March 2019; Accepted: 23 April 2019; Published: 24 April 2019

check for updates

\begin{abstract}
Two binuclear coordination compounds of $\mathrm{Cu}(\mathrm{II})$ chloride with the bitopic ligand 1,1,2,2-tetrakis(pyrazol-1-yl)ethane $\left(\mathrm{Pz}^{4}\right)$ of the composition $\left[\mathrm{Cu}_{2}\left(\mu_{2}-\mathrm{Pz}^{4}\right)(\mathrm{DMSO})_{2} \mathrm{Cl}_{4}\right] \cdot 4 \mathrm{H}_{2} \mathrm{O}$ and $\left[\mathrm{Cu}_{2}\left(\mu_{2}-\mathrm{Pz}^{4}\right)(\mathrm{DMSO})_{2} \mathrm{Cl}_{4}\right] \cdot 2 \mathrm{DMSO}$ were prepared and characterized by elemental analysis, IR spectroscopy, thermogravimetric analysis, single-crystal $X$-ray diffraction, and powder diffraction analysis. It was shown that in contrast to silver(I) and copper(II) nitrates, copper(II) chloride forms discrete complexes instead of coordination polymers. The supramolecular structure of the complex $\left[\mathrm{Cu}_{2}\left(\mu_{2}-\mathrm{Pz}^{4}\right)(\mathrm{DMSO})_{2} \mathrm{Cl}_{4}\right] \cdot 4 \mathrm{H}_{2} \mathrm{O}$ with lattice water molecules is formed by $\mathrm{OH} \cdots \mathrm{Cl}$ and $\mathrm{OH} \cdots \mathrm{O}$ hydrogen bonds. Density functional theory (DFT) calculations of vibrational frequencies of the ligand and its copper(II) complex allowed for assigning IR bands to specific vibrations.
\end{abstract}

Keywords: 1,1,2,2-tetrakis(pyrazol-1-yl)ethane; copper(II) chloride; bitopic ligand; thermogravimetric analysis; binuclear complexes; crystal structure

\section{Introduction}

Multitopic ligands are a class of ligands that nowadays have attracted an increasing amount of interest in many applications of coordination chemistry. These ligands contain two or more separated metal-binding sites that allow them to form a wide variety of structures [1-3]. The design of a linker structure between the binding sites permits tuning the properties of the materials based on coordination compounds with multitopic ligands [4-7]. Applications of functional materials containing such ligands include gas storage [8-10], membrane separations [11], electrochemical devices [12], sensing materials [13,14], drug delivery systems [15,16], enantiomer separations [17], and catalysis in fine organic synthesis $[18,19]$.

Bitopic bis- and tris(pyrazol-1yl)methanes have served as ligands for the preparation of various silver coordination polymers of different topologies [20-28]. In our recent work, we synthesized silver coordination polymers containing the bitopic ligand 1,1,2,2-tetra(pyrazol-1-yl)ethane ( $\mathrm{Pz}^{4}$ ) and showed that silver-based compounds are more likely to form polymeric rather than discrete structures [29]. For the case of $\mathrm{Cu}^{2+}$ ions, we demonstrated that both molecular copper(II) complexes and coordination polymers can be prepared [30,31]. Catalytic activity of the binuclear palladium(II) complex of $\mathrm{Pz}^{4}$ [32] 
as well as antibacterial and antifungal activity of the ligand itself [33] were reported recently. In this work, we focused on the synthesis and crystal structure peculiarities of $\mathrm{Cu}(\mathrm{II})$ coordination compounds containing the $\mathrm{Pz}^{4}$ ligand. Herein, we report the first $\mathrm{X}$-ray crystal structures of the pure ligand and two new copper(II) coordination compounds and discuss their peculiarities.

\section{Materials and Methods}

\subsection{Instrumental Characterization Methods}

Elemental analysis (C, H, N, and S) was carried out on Euro EA 3000 analyzer (Eurovector SPA, Redavalle, Italy) following the standard procedures.

IR spectra of the complexes as mineral and fluorinated oil mulls or polyethylene pellets were recorded on Scimitar FTS 2000 (Digilab LLC, Canton, MA, USA) and Vertex 80 (Bruker Corporation, Billerica, MA, USA) spectrometers in the range of $4000-100 \mathrm{~cm}^{-1}$.

X-ray powder diffraction (XRD) patterns were recorded at room temperature on a DRON-RM4 diffractometer (Burevestnik, Saint Petersburg, Russia) using $\mathrm{Cu} K_{\alpha}$ irradiation and graphite monochromator $d_{001}=3345 \AA$. The scanning range was $5^{\circ}-60^{\circ}(2 \theta)$ for complex salts and $5^{\circ}-90^{\circ}(2 \theta)$ for products of thermolysis. The experimental diffraction data were processed using the PowderCell v.2.4 program [34], which allowed a calculation of the quantitative phase composition and the lattice parameters. Data from the PDF database [35] were used as reference.

Thermogravimetric analysis of coordination compounds was carried out in helium atmosphere on a NETZSCH thermobalance TG 209 F1 Iris (Erich NETZSCH GmbH \& Co. Holding KG, Selb, Germany) in open $\mathrm{Al}_{2} \mathrm{O}_{3}$ crucibles (loads of 5-10 $\mathrm{mg}$, heating rate of $10 \mathrm{~K} \cdot \mathrm{min}^{-1}$ ).

\subsection{X-ray Structure Determination}

The single crystals of compounds $\mathrm{Pz}^{4}, \mathbf{1}$, and $\mathbf{2}$ were selected directly from the mother liquors and mounted on glass fibers using epoxy resin. Single-crystal X-ray diffraction data were collected on a Bruker-Nonius X8 APEX CCD diffractometer (graphite monochromatized Mo K $\alpha$ radiation, $\lambda=0.71073 \AA, \varphi$ and $\omega$ scans of narrow frames (Bruker Corporation, Billerica, MA, USA), equipped with a $4 \mathrm{~K}$ CCD area detector (Table 1). Absorption corrections were applied using the SADABS program [36]. The crystal structures were solved by direct methods and refined by full-matrix least-squares techniques with the use of the SHELXTL package [37] and Olex2 GUI [38]. Atomic thermal displacement parameters for nonhydrogen atoms were refined anisotropically. The positions of $\mathrm{H}$ atoms were calculated corresponding to their geometrical conditions and refined using the riding model.

\subsection{Computational Chemistry}

Experimental X-Ray structures of the ligand $\mathrm{Pz}^{4}$ and complex 1 (without uncoordinated dimethyl sulfoxide (DMSO) molecules) were used as starting points for density functional theory (DFT) geometry optimizations. Singlet- (for $\mathrm{Pz}^{4}$ ) or triplet-state (for complex 1) gas-phase geometry optimizations were carried out at the DFT level of theory employing the three-parameter hybrid B3LYP functional [39-42] and $6-31+\mathrm{G}(\mathrm{d})$ basis set [43] in the Gaussian 09 package [44]. Frequency calculations were performed for both molecules in order to ensure the lack of imaginary vibration frequencies, which indicates that the optimized structures correspond to minima on the potential energy surfaces. Cartesian atomic coordinates for all of the optimized structures are provided in Supplementary Tables S1 and S2.

Hirshfeld promolecular surfaces mapped over $\mathrm{d}_{\text {norm }}$ plots of the complexes were built using the Crystal Explorer (version 17.5) program [45]. 


\subsection{Synthesis of Compounds}

Analysis-grade copper(II) chloride dihydrate was used for the synthesis of the complexes. $\mathrm{Pz}^{4}$ was prepared as described previously [46]. Solvents were of reagent-grade purity and were used as received.

\subsubsection{Synthesis of $\left[\mathrm{Cu}_{2}\left(\mu_{2}-\mathrm{Pz}^{4}\right)(\mathrm{DMSO})_{2} \mathrm{Cl}_{4}\right] \cdot 4 \mathrm{H}_{2} \mathrm{O}(\mathbf{1})$}

A hot suspension containing $\mathrm{Pz}^{4}(0.3 \mathrm{mmol}, 0.09 \mathrm{~g})$ in $5 \mathrm{ml}$ of DMSO was added with stirring to an ethanol solution $(7 \mathrm{ml})$ of $\mathrm{CuCl}_{2} \cdot 2 \mathrm{H}_{2} \mathrm{O}(1.5 \mathrm{mmol}, 0.25 \mathrm{~g})$. Green crystals of 1 suitable for X-ray diffraction analysis were obtained by slow crystallization over the course of $24 \mathrm{~h}$. The light-green precipitate formed from the solution was filtered, washed with ethanol, and then dried in the air. The yield of the product was $0.13 \mathrm{~g}(55 \%)$. Elemental analysis: found, \%: C 27.6; H 4.2; N 14.4; $\mathrm{S}$ 8.0; for $\mathrm{C}_{18} \mathrm{H}_{34} \mathrm{Cl}_{4} \mathrm{Cu}_{2} \mathrm{~N}_{8} \mathrm{O}_{6} \mathrm{~S}_{2}$ calculated, \%: C 27.3; $\mathrm{H} 4.3 ; \mathrm{N} 14.2 ; \mathrm{S}$ 8.1. IR bands, $\mathrm{cm}^{-1}: 3513,3424(v \mathrm{OH}$ $\left.\left(\mathrm{H}_{2} \mathrm{O}\right)\right), 3125,3101,2987(v \mathrm{CH}(\mathrm{Pz})), 1630\left(\delta \mathrm{OH}\left(\mathrm{H}_{2} \mathrm{O}\right)\right), 1513(v \mathrm{CH}(\mathrm{Pz})), 467(v(\mathrm{Cu}-\mathrm{O})), 295(v(\mathrm{Cu}-\mathrm{N}))$, $254(v(\mathrm{Cu}-\mathrm{Cl}))$.

Table 1. Crystallographic data of the compounds 1,1,2,2-tetra(pyrazol-1-yl)ethane (Pz $\left.{ }^{4}\right), 1$, and 2.

\begin{tabular}{|c|c|c|c|}
\hline Identification Code & $\mathbf{P z}^{4}$ & 1 & 2 \\
\hline Empirical formula & $\mathrm{C}_{14} \mathrm{H}_{14} \mathrm{~N}_{8}$ & $\mathrm{C}_{18} \mathrm{H}_{34} \mathrm{Cl}_{4} \mathrm{Cu}_{2} \mathrm{~N}_{8} \mathrm{O}_{6} \mathrm{~S}_{2}$ & $\mathrm{C}_{22} \mathrm{H}_{38} \mathrm{Cl}_{4} \mathrm{Cu}_{2} \mathrm{~N}_{8} \mathrm{O}_{4} \mathrm{~S}_{4}$ \\
\hline Formula weight & 294.33 & 791.53 & 875.72 \\
\hline Temperature/K & $150(2)$ & $296(2)$ & $150(2)$ \\
\hline Crystalsystem & monoclinic & triclinic & monoclinic \\
\hline Spacegroup & $\mathrm{C} 2 / \mathrm{c}$ & $P-1$ & $P 2_{1} / c$ \\
\hline $\mathrm{a} / \AA$ & $15.0087(9)$ & $7.959(3)$ & $8.7218(4)$ \\
\hline $\mathrm{b} / \AA$ & $5.4385(3)$ & $8.885(3)$ & $18.2205(7)$ \\
\hline$c / \AA ̊$ & $17.3736(11)$ & $12.269(5)$ & $11.9231(5)$ \\
\hline$\alpha /^{\circ}$ & 90 & $73.239(16)$ & 90 \\
\hline$\beta /{ }^{\circ}$ & $92.435(2)$ & $72.615(16)$ & $107.0408(16)$ \\
\hline$\gamma /{ }^{\circ}$ & 90 & $83.178(18)$ & 90 \\
\hline Volume $/ \AA^{3}$ & $1416.84(15)$ & $792.3(5)$ & $1811.58(13)$ \\
\hline Z & 4 & 1 & 2 \\
\hline$\rho_{\text {calc }} \mathrm{g} / \mathrm{cm}^{3}$ & 1.380 & 1.659 & 1.605 \\
\hline$\mu / \mathrm{mm}^{-1}$ & 0.092 & 1.857 & 1.740 \\
\hline $\mathrm{F}(000)$ & 616.0 & 404.0 & 896.0 \\
\hline Crystalsize $/ \mathrm{mm}^{3}$ & $0.35 \times 0.1 \times 0.09$ & $0.25 \times 0.15 \times 0.1$ & $0.2 \times 0.12 \times 0.1$ \\
\hline $2 \Theta$ range for data collection $/{ }^{\circ}$ & $4.694-55.148$ & $4.792-55.588$ & $4.214-52.818$ \\
\hline Index ranges & $\begin{aligned}-19 & \leq \mathrm{h} \leq 14 \\
-7 & \leq \mathrm{k} \leq 4 \\
-20 & \leq 1 \leq 22\end{aligned}$ & $\begin{array}{c}-9 \leq \mathrm{h} \leq 10 \\
-11 \leq \mathrm{k} \leq 11 \\
-14 \leq 1 \leq 15\end{array}$ & $\begin{array}{l}-10 \leq \mathrm{h} \leq 10 \\
-22 \leq \mathrm{k} \leq 22 \\
-14 \leq 1 \leq 14\end{array}$ \\
\hline Reflections collected & 3290 & 6095 & 24618 \\
\hline Independent reflections & $\begin{array}{c}1628\left[R_{\text {int }}=0.0167\right. \\
\left.R_{\text {sigma }}=0.0257\right]\end{array}$ & $\begin{array}{c}3598\left[R_{\text {int }}=0.0391\right. \\
\left.R_{\text {sigma }}=0.0579\right]\end{array}$ & $\begin{array}{c}3715\left[R_{\text {int }}=0.0328,\right. \\
\left.R_{\text {sigma }}=0.0217\right]\end{array}$ \\
\hline Restraints/parameters & $0 / 100$ & $0 / 189$ & $0 / 203$ \\
\hline Goodness-of-fit on $\mathrm{F}^{2}$ & 1.053 & 1.044 & 1.035 \\
\hline Final $R$ indexes $[I \geq 2 \sigma(I)]$ & $\mathrm{R}_{1}=0.0386, \mathrm{wR}_{2}=0.0964$ & $\mathrm{R}_{1}=0.0424, \mathrm{wR}_{2}=0.1092$ & $\mathrm{R}_{1}=0.0252, \mathrm{wR}_{2}=0.0556$ \\
\hline Final $\mathrm{R}$ indexes [all data] & $\mathrm{R}_{1}=0.0494, \mathrm{wR}_{2}=0.1029$ & $\mathrm{R}_{1}=0.0584, \mathrm{wR}_{2}=0.1153$ & $\mathrm{R}_{1}=0.0313, \mathrm{wR}_{2}=0.0580$ \\
\hline Largest diff. peak/hole / e $\AA^{-3}$ & $0.31 /-0.23$ & $0.70 /-0.47$ & $0.74 /-0.30$ \\
\hline
\end{tabular}

\subsubsection{Synthesis of $\left[\mathrm{Cu}_{2}\left(\mu_{2}-\mathrm{Pz}^{4}\right)(\mathrm{DMSO})_{2} \mathrm{Cl}_{4}\right] \cdot 2 \mathrm{DMSO}(2)$.}

A suspension of $26.0 \mathrm{mg} \mathrm{Pz}{ }^{4}(0.09 \mathrm{mmol})$ in $1 \mathrm{ml}$ of DMSO was added to $34.0 \mathrm{mg}$ of $\mathrm{CuCl}_{2} \cdot 2 \mathrm{H}_{2} \mathrm{O}$ $(0.2 \mathrm{mmol})$ in a glass vial. The mixture was stirred for $10 \mathrm{~min}$ at room temperature. During the stirring process, a light-green precipitate formed. The vial with the formed powder was placed into an oven at $95^{\circ} \mathrm{C}$. After $18 \mathrm{~h}$ of heating, the vial was allowed to cool to room temperature. After one day, the crystals initially formed on the bottom of the vial were filtered and washed once with $1 \mathrm{ml}$ of DMSO and then air-dried for a few days. The yield of the product was $39.9 \mathrm{mg}(52 \%)$. Elemental analysis: found, \%: C 29.6; $\mathrm{H}$ 4.0; $\mathrm{N}$ 12.9; $\mathrm{S}$ 14.3; for $\mathrm{C}_{22} \mathrm{H}_{38} \mathrm{Cl}_{4} \mathrm{Cu}_{2} \mathrm{~N}_{8} \mathrm{O}_{4} \mathrm{~S}_{4}$ calculated, \%: C 30.2; $\mathrm{H} 4.4 ; \mathrm{N}$ 12.8; S 14.6. IR bands, $\mathrm{cm}^{-1}: 3141,3094,3000(v \mathrm{CH}(\mathrm{Pz})), 1513(v \mathrm{CH}(\mathrm{Pz})), 481(v(\mathrm{Cu}-\mathrm{O})), 294(v(\mathrm{Cu}-\mathrm{N}))$, $260(v(\mathrm{Cu}-\mathrm{Cl}))$. 


\section{Results and Discussion}

\subsection{Synthesis of the Complexes}

The two copper(II) chloride complexes with ligand $\mathrm{Pz}^{4}$ were synthesized by the reaction of the ethanol solution of the $\mathrm{CuCl}_{2} \cdot 2 \mathrm{H}_{2} \mathrm{O}$ (for 1 ) or solid copper salt (for 2 ) with the DMSO suspension of 1,1,2,2-tetrakis(pyrazol-1-yl)ethane according to Scheme 1.

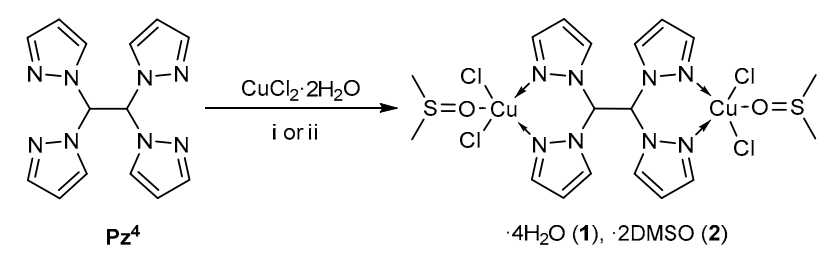

Scheme 1. Synthesis route of copper chloride complexes $\mathbf{1}$ and 2. i: DMSO-EtOH, $25^{\circ} \mathrm{C}$ (for complex 1); ii: DMSO, $95^{\circ} \mathrm{C}$ (for complex 2).

The synthesis of complex $\mathbf{1}$ was carried out with stirring at room temperature followed by slow crystallization from solution over the course of $24 \mathrm{~h}$. Complex 1 was synthesized at the ratio $\mathrm{Cu}^{2+}: \mathrm{Pz}^{4}=5: 1$. Complex 2 was obtained after $18 \mathrm{~h}$ of heating at $95{ }^{\circ} \mathrm{C}$ of the reaction mixture using solid copper salt at the $\mathrm{Cu}^{2+}: \mathrm{Pz}^{4}$ ratio of 2.2:1. Although complexes 1 and $\mathbf{2}$ differed only in outer-sphere solvate molecules, they demonstrated different crystal packing and different thermal behavior.

\subsection{Crystal Structures of the Complexes}

The compounds $\left[\mathrm{Cu}_{2}\left(\mathrm{Pz}^{4}\right)(\mathrm{DMSO})_{2} \mathrm{Cl}_{4}\right] \cdot 4 \mathrm{H}_{2} \mathrm{O}(\mathbf{1})$ and $\left[\mathrm{Cu}_{2}\left(\mathrm{Pz}^{4}\right)(\mathrm{DMSO})_{2} \mathrm{Cl}_{4}\right] \cdot 2 \mathrm{DMSO}(2)$ include water and DMSO solvate molecules, respectively, and are not isostructural. Both complexes are centrosymmetric binuclear (Figure 1) and reveal very similar molecular geometries. Cu atoms coordinate two $\mathrm{Cl}^{-}$ligands, one $\mathrm{O}$ atom of DMSO ligand, and two $\mathrm{N}$ atoms of $\mathrm{Pz}^{4}$. Addison's $\tau_{5}$ criterion [47] was used to determine the geometry of coordination polyhedra of copper(II) ions in complexes 1 and 2 (Table 2). As suggested by the $\tau_{5}$ criterion, the environment of the central atom in complex 1 is a slightly distorted trigonal bipyramid with $\mathrm{O}$ and $\mathrm{N}$ atoms located in axial positions, while in complex $\mathbf{2}$, the arrangement is more distorted toward square pyramidal. In previously reported structures of two binuclear copper(II) nitrate polymorphs $\left[\mathrm{Cu}_{2}\left(\mathrm{Pz}^{4}\right)\left(\mathrm{H}_{2} \mathrm{O}\right)_{2}\left(\mathrm{NO}_{3}\right)_{4}\right][30,31]$, the $\tau_{5}$ criterion had values in the range of $0.01-0.19$, indicative of a square planar geometry of coordination sphere comprising two monodentate nitrate ions, two nitrogen atoms of the ligand, and one water molecule. Thus, the $\mathrm{Pz}^{4}$ ligand shields the central atom in a chelate mode, leaving enough space for three more ligands (chloride/nitrate and solvent molecules). However, it can provide space even for four ligands, as shown by the example of polymeric nitrate complexes $\left[\mathrm{Cu}\left(\mathrm{Pz}^{4}\right)\left(\mathrm{NO}_{3}\right)_{2}\right]_{\mathrm{n}}$ and $\left[\left\{\mathrm{Cu}\left(\mathrm{Pz}^{4}\right)\left(\mathrm{H}_{2} \mathrm{O}\right)\left(\mathrm{NO}_{3}\right)_{2}\right\}_{2}\right]_{\mathrm{n}}[31]$, which reveal a highly distorted (4+2) octahedral environment. Copper-donor-atom bond lengths and bond angles are very similar in both complexes $\mathbf{1}$ and $\mathbf{2}$, with the exception of the $\mathrm{Cu}-\mathrm{Cl}$ distance being larger by $0.10 \AA$ for complex 2 in respect to 1 . The metallocycles in 1, 2, and known copper(II) complexes with $\mathrm{Pz}^{4}$ have similar geometries, implying their inflexibility (Supplementary Materials Figure S1). The relative positions of one pyrazole unit and DMSO ligand are slightly different for $\mathbf{1}$ and $\mathbf{2}$ (Supplementary Materials Figure S2), which is likely due to intermolecular interactions with the solvent molecules and/or packing effects. Analysis of normalized contact distance $\left(\mathrm{d}_{\text {norm }}\right)$ mapping on the promolecular Hirshfeld surface of the $\mathrm{Pz}^{4}$ ligand revealed intramolecular $\mathrm{C}-\mathrm{H} \cdots \mathrm{Cl}$ contacts between the ethane unit of $\mathrm{Pz}^{4}$ and chloride in both compounds 1 and 2 (Figure 2), being noticeably shorter for the latter. The same type of $\mathrm{C}-\mathrm{H} \cdots \mathrm{O}$ contacts with nitrates in place of chlorides has been observed in known complexes $\left[\mathrm{Cu}\left(\mathrm{Pz}^{4}\right)\left(\mathrm{NO}_{3}\right)_{2}\right]_{\mathrm{n}}$ and $\left[\left\{\mathrm{Cu}\left(\mathrm{Pz}^{4}\right)\left(\mathrm{H}_{2} \mathrm{O}\right)\left(\mathrm{NO}_{3}\right)_{2}\right\}_{2}\right]_{\mathrm{n}}[31]_{\text {. }}$. In other words, $\mathrm{Cl}^{-}$and $\mathrm{NO}_{3}{ }^{-}$are inclined to $\mathrm{C}-\mathrm{H}$ of the ethane unit. However, two polymorphs $\left[\mathrm{Cu}_{2}\left(\mathrm{Pz}^{4}\right)\left(\mathrm{H}_{2} \mathrm{O}\right)_{2}\left(\mathrm{NO}_{3}\right)_{4}\right][30,31]$ show different arrangement of nitrates, which lie on both sides of the corresponding $\mathrm{C}-\mathrm{H}$ line. In this way, they are inclined to $\mathrm{C}-\mathrm{H}$ of the pyrazole unit. Considering the 
large distance between $\mathrm{C}-\mathrm{H}$ and the donor atoms as well as the very low polarity of the $\mathrm{C}-\mathrm{H}$ bonds, these types of contacts are likely to have a steric nature.

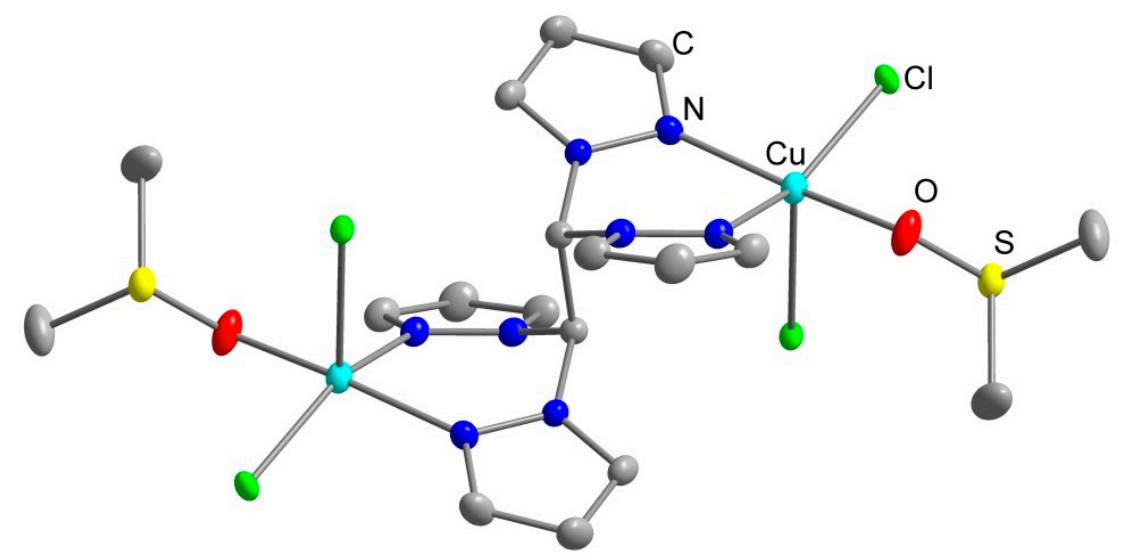

Figure 1. Atomic displacement ellipsoid plot of the complexes $\left[\mathrm{Cu}_{2}\left(\mathrm{Pz}^{4}\right)(\mathrm{DMSO})_{2} \mathrm{Cl}_{4}\right] \cdot 4 \mathrm{H}_{2} \mathrm{O}(\mathbf{1})$ and $\left[\mathrm{Cu}_{2}\left(\mathrm{Pz}^{4}\right)(\mathrm{DMSO})_{2} \mathrm{Cl}_{4}\right] \cdot 2 \mathrm{DMSO}(2)$ on the example of the latter. Uncoordinated solvent molecules and hydrogen atoms are omitted for clarity.

Table 2. Addison's $\tau_{5}$ criterion for coordination centers in the complexes in copper(II) complexes with $\mathrm{Pz}^{4}$ ligand.

\begin{tabular}{ccccc}
\hline Parameter & $\alpha$ & $\beta$ & $\tau_{5}=(\beta-\alpha) / 60$ & References \\
\hline$\left[\mathrm{Cu}_{2}\left(\mathrm{Pz}^{4}\right)(\mathrm{DMSO})_{2} \mathrm{Cl}_{4}\right] \cdot 4 \mathrm{H}_{2} \mathrm{O}(\mathbf{1})$ & 129.0 & 171.7 & 0.71 & This paper \\
{$\left[\mathrm{Cu}_{2}\left(\mathrm{Pz}^{4}\right)\left(\mathrm{DMSO}_{2} \mathrm{Cl}_{4}\right] \cdot 2 \mathrm{DMSO}(\mathbf{2})\right.$} & 153.1 & 168.7 & 0.26 & This paper \\
{$\left[\mathrm{Cu}_{2}\left(\mathrm{Pz}^{4}\right)\left(\mathrm{H}_{2} \mathrm{O}\right)_{2}\left(\mathrm{NO}_{3}\right)_{4}\right]$} & $176.0,178.3$ & $168.1,172.2$ & $0.06,0.17$ & {$[30]$} \\
{$\left[\mathrm{Cu}_{2}\left(\mathrm{Pz}^{4}\right)\left(\mathrm{H}_{2} \mathrm{O}\right)_{2}\left(\mathrm{NO}_{3}\right)_{4}\right]$} & $179.3,176.1,177.2,179.5$ & $170.2,175.4,173.1,168.2$ & $0.15,0.01,0.07,0.19$ & {$[31]$} \\
\hline
\end{tabular}

In complex 1, both crystallographically independent $\mathrm{Cl}$ atoms form weak intermolecular hydrogen bonds with two water molecules (Figure 3) $(\mathrm{O} \cdots \mathrm{Cl}$ distances are 3.21 and $3.35 \AA$ ). Hydrogen bonds between water molecules were also observed ( $\mathrm{O} \cdots \mathrm{O}$ distances are 2.78 and $2.80 \AA$ ), revealing a layered supramolecular structure. Analysis of the Hirshfeld surface revealed intermolecular contacts $\mathrm{C}-\mathrm{H} \cdots \mathrm{D}$ $(\mathrm{D}=\mathrm{Cl}, \mathrm{O})$ between molecules of the complexes and solvates in $\mathbf{1}$ and $\mathbf{2}$ (Supplementary Materials Figure S3) as well as in known copper(II) complexes [30,31], but they are likely to have a steric nature due to the low polarity of the $\mathrm{C}-\mathrm{H}$ bonds. Overall crystal packing of $\mathbf{1}$ and $\mathbf{2}$ is somewhat close: one can distinguish chains built from the molecules, which are arranged along $\mathrm{Cu} \cdots$ (center of $\left.\mathrm{Pz}^{4}\right) \cdots \mathrm{Cu}$ mean line (Supplementary Materials Figure S4). The same type of chain was observed in the coordination polymers $\left[\mathrm{Cu}\left(\mathrm{Pz}^{4}\right)\left(\mathrm{NO}_{3}\right)_{2}\right]_{\mathrm{n}}[31],\left[\mathrm{Ag}\left(\mathrm{Pz}^{4}\right)\left(\mathrm{NO}_{3}\right)\right]_{\mathrm{n}}$, and $\left\{\left[\mathrm{Ag}\left(\mathrm{Pz}^{4}\right)\left(\mathrm{NO}_{3}\right)\right] \mathrm{DMF}\right\}_{\mathrm{n}}[29]$. In 1 and 2, the $\mathrm{Cu} \cdots \mathrm{Cu}$ distances within the molecule were 6.78 and $6.81 \AA$, while those between neighboring molecules in the chain were 7.14 and $7.94 \AA$, correspondingly.

\subsection{Crystal Structure of the Ligand $P z^{4}$}

Conformation of the $\mathrm{Pz}^{4}$ molecule in the solid state differs from that in the complexes. In free $\mathrm{Pz}^{4}$, the $\mathrm{C} 1-\mathrm{C} 1^{\prime}-\mathrm{N} 11-\mathrm{N} 12$ torsion angle (of $130.1^{\circ}$ ) characteristic for the rotation of one of the pyrazole rings around the $\mathrm{C}^{\prime}-\mathrm{N} 11$ bond is obtuse (Figure 4). In contrast, all known complexes revealed acute torsion angles for both pyrazole rings due to chelate coordination of the ligand (Table 3). Note that the angle in copper(II) complexes falls within the $59^{\circ}-72^{\circ}$ range, while that in silver(I) compounds lies in the range of $50^{\circ}-58^{\circ}$, which is in accordance with the increased ionic radius of $\mathrm{Ag}^{+}$as compared with $\mathrm{Cu}^{2+}$. 


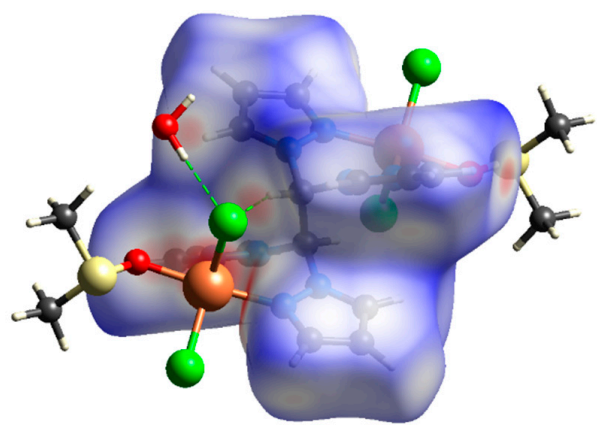

$\left[\mathrm{Cu}_{2}\left(\mu_{2}-\mathrm{Pz}^{4}\right)(\mathrm{DMSO})_{2} \mathrm{Cl}_{4}\right] \cdot 4 \mathrm{H}_{2} \mathrm{O}(\mathbf{1})$

C... $\mathrm{Cl}$ distance of $3.52 \AA$

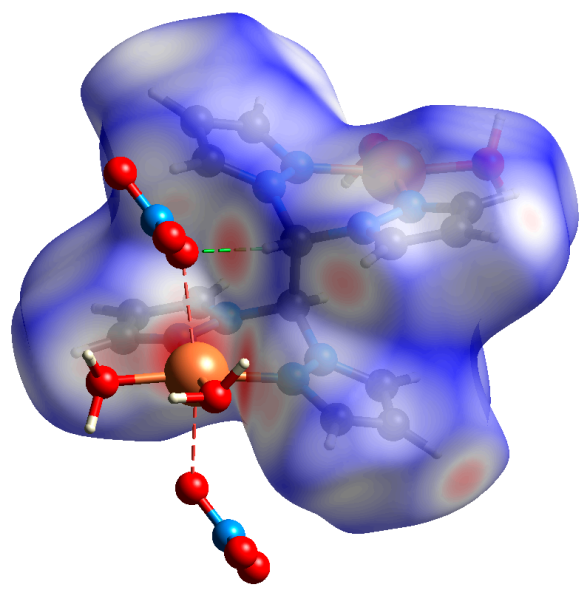

$\left[\left\{\mathrm{Cu}\left(\mathrm{Pz}^{4}\right)\left(\mathrm{H}_{2} \mathrm{O}\right)\left(\mathrm{NO}_{3}\right)_{2}\right\}_{2}\right]_{\mathrm{n}}$ (Refcode PUZSAG) [31] C...O distance of $3.10 \AA$

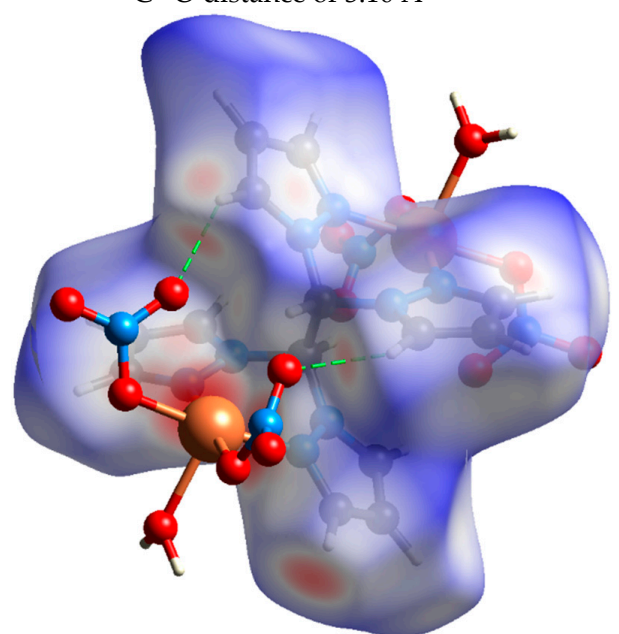

[Cu2 $\left.\left(\mathrm{Pz}^{4}\right)\left(\mathrm{H}_{2} \mathrm{O}\right)_{2}\left(\mathrm{NO}_{3}\right)_{4}\right]$ (Refcode XUDWUQ) [30]

C...O distances of 3.22, 3.28, 3.14, and $3.29 \AA$

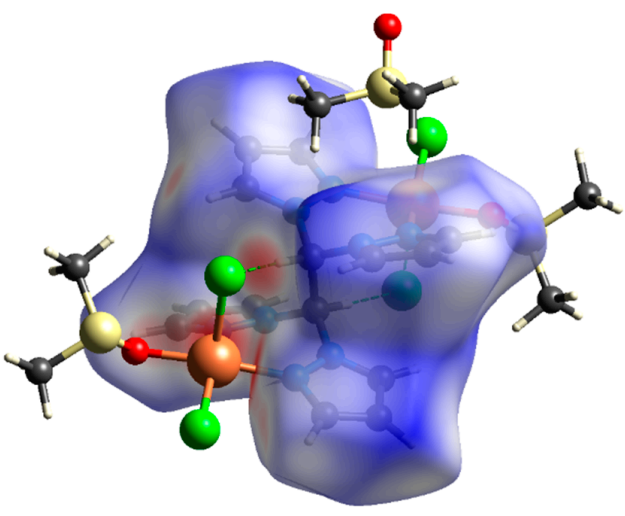

$\left[\mathrm{Cu}_{2}\left(\mu_{2}-\mathrm{Pz}^{4}\right)(\mathrm{DMSO})_{2} \mathrm{Cl}_{4}\right] \cdot 2 \mathrm{DMSO}(\mathbf{2})$

$\mathrm{C} \cdots \mathrm{Cl}$ distance of $3.28 \AA$

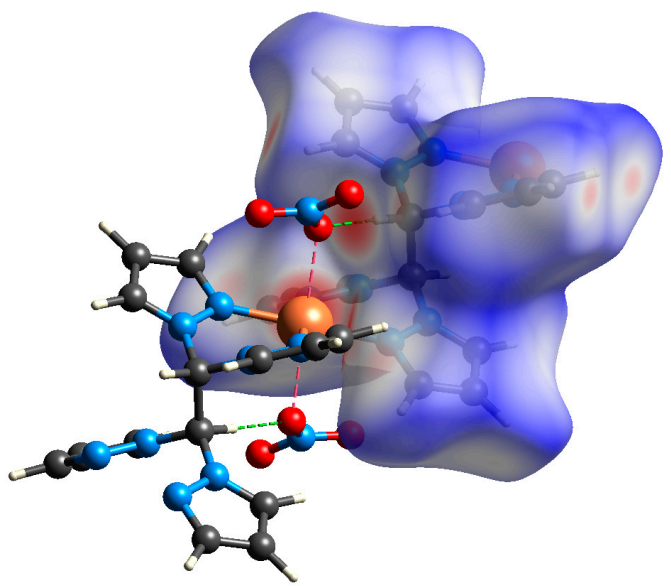

$\left[\mathrm{Cu}\left(\mathrm{Pz}^{4}\right)\left(\mathrm{NO}_{3}\right)_{2}\right]_{\mathrm{n}}$ (Refcode PUZSEK) [31] C...O distance of $2.94 \AA$

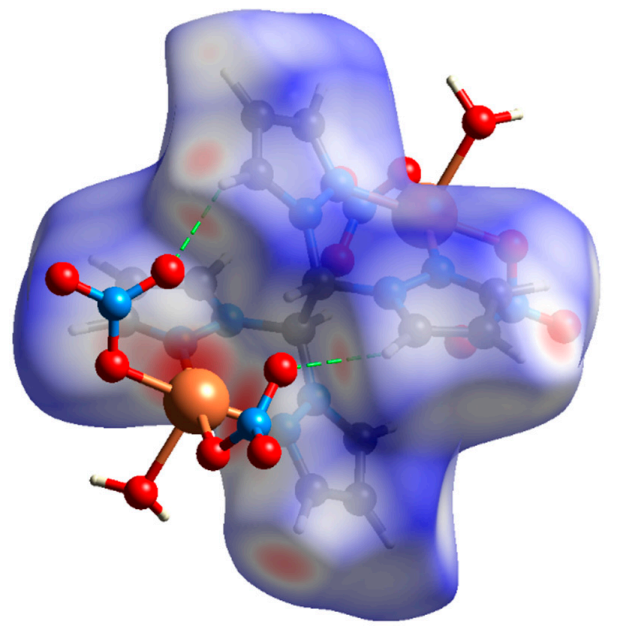

[Cu2 $\left.\left(\mathrm{Pz}^{4}\right)\left(\mathrm{H}_{2} \mathrm{O}\right)_{2}\left(\mathrm{NO}_{3}\right)_{4}\right]$ (Refcode XUDWUQ01) [31] $\mathrm{C} \cdots \mathrm{O}$ distances of $3.22,3.31,3.26,3.29,3.23$, $3.27,3.26$, and $3.36 \AA$

Figure 2. The $\mathrm{d}_{\text {norm }}$ Hirshfeld surface of $\mathrm{Pz}^{4}$ ligand in the copper(II) complexes showing intramolecular $\mathrm{C}-\mathrm{H} \cdots \mathrm{D}(\mathrm{D}=\mathrm{Cl}, \mathrm{O})$ contacts (marked dashed green). Area with intermolecular contacts closer than the sum of the atoms' van der Waals radii are red, longer contacts are blue, and the contacts around the sum of van der Waals radii are white. For polymeric complexes, only the ligand and coordination environment of the central atom are shown. For $\left[\mathrm{Cu}_{2}\left(\mathrm{Pz}^{4}\right)\left(\mathrm{H}_{2} \mathrm{O}\right)_{2}\left(\mathrm{NO}_{3}\right)_{4}\right]$ (Refcode XUDWUQ01), only one of two crystallographically independent molecules is shown. 


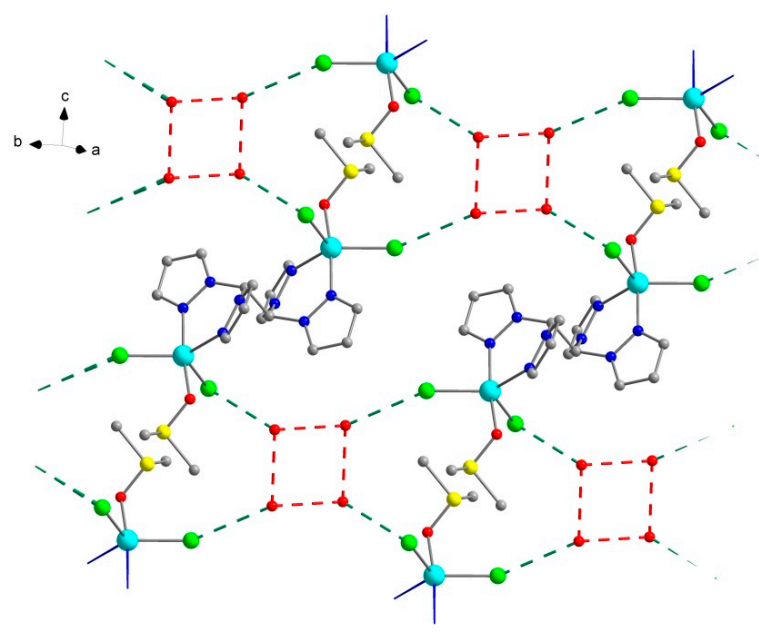

Figure 3. Packing diagram of $\left[\mathrm{Cu}_{2}\left(\mathrm{Pz}^{4}\right)(\mathrm{DMSO})_{2} \mathrm{Cl}_{4}\right] \cdot 4 \mathrm{H}_{2} \mathrm{O}(\mathbf{1})$ showing $\mathrm{OH} \cdots \mathrm{Cl}$ (dashed green lines) and $\mathrm{OH} \cdots \mathrm{O}$ (dashed red lines) hydrogen bonds, which form a layered structure. Hydrogen atoms are omitted for clarity.

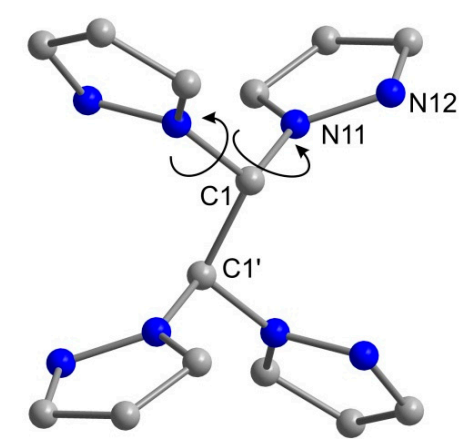

Figure 4. Structure of $\mathrm{Pz}^{4}$, showing the $\mathrm{C} 1-\mathrm{C}^{\prime}-\mathrm{Nn} 1-\mathrm{Nn} 2(\mathrm{n}=1,2)$ torsion angle. Hydrogen atoms are omitted for clarity.

Table 3. Torsion angles of $\mathrm{Pz}^{4}$ in solid state and in copper(II) and silver(I) complexes.

\begin{tabular}{ccc}
\hline Compound & $\mathbf{C 1}-\mathbf{C 1}^{\prime}-\mathbf{N n 1 - N n 2 ~} \mathbf{( n = 1 , 2 )}$ Torsion Angle ${ }^{\circ}$ & References \\
\hline $\mathrm{Pz}^{4}$ & $\pm 130.1, \pm 50.9$ & This paper \\
{$\left[\mathrm{Cu}_{2}\left(\mathrm{Pz}^{4}\right)(\mathrm{DMSO})_{2} \mathrm{Cl}_{4}\right] \cdot 4 \mathrm{H}_{2} \mathrm{O}(\mathbf{1})$} & $\pm 71,8 ; \pm 59.5$ & This paper \\
{$\left[\mathrm{Cu}_{2}\left(\mathrm{Pz}^{4}\right)(\mathrm{DMSO})_{2} \mathrm{Cl}_{4}\right] \cdot 2 \mathrm{DMSO}(\mathbf{2})$} & $\pm 69,6 ; \pm 64.4$ & This paper \\
{$\left[\mathrm{Cu}_{2}\left(\mathrm{Pz}^{4}\right)\left(\mathrm{H}_{2} \mathrm{O}\right)_{2}\left(\mathrm{NO}_{3}\right)_{4}\right]$} & $60.8 ;-70.4 ; 69.1 ;-61.7$ & {$[30]$} \\
{$\left[\mathrm{Cu}_{2}\left(\mathrm{Pz}^{4}\right)\left(\mathrm{H}_{2} \mathrm{O}\right)_{2}\left(\mathrm{NO}_{3}\right)_{4}\right]$} & $70.4 ;-61.5 ; 63.2 ;-67.0$ & {$[31]$} \\
{$\left[\mathrm{Cu}\left(\mathrm{Pz}^{4}\right)\left(\mathrm{NO}_{3}\right)_{2}\right]_{\mathrm{n}}$} & $59.5 ;-74.9 ; 67.7 ;-61.0$. & {$[31]$} \\
{$\left[\left\{\mathrm{Cu}\left(\mathrm{Pz}^{4}\right)\left(\mathrm{H}_{2} \mathrm{O}\right)\left(\mathrm{NO}_{3}\right)_{2}\right\}_{2}\right]_{\mathbf{n}}$} & $\pm 72.2 ; \pm 61.5 ;$ & {$[31]$} \\
$\left\{\left[\mathrm{Ag}\left(\mathrm{Pz}^{4}\right)\left(\mathrm{NO}_{3}\right)\right] \mathrm{DMF}_{\mathrm{n}}\right.$ & $\pm 70.0 ; \pm 72.5$ & {$[29]$} \\
{$\left[\left\{\mathrm{Ag}\left(\mathrm{Pz}^{4}\right)\left(\mathrm{NO}_{3}\right)\right\}_{\mathrm{n}}\right]$} & $\pm 57.9 ; \pm 53.8 ; \pm 50.4 ; \pm 54.8$ & {$[29]$} \\
\hline
\end{tabular}

\subsection{IR Spectroscopy and DFT Calculations}

For more accurate interpretation of IR spectra of the $\mathrm{Pz}^{4}$ ligand and its copper(II) chloride complexes, DFT calculations of geometries of isolated molecules and normal mode vibration frequencies were carried out.

Calculated and experimental (from X-Ray single-crystal structural analysis) geometrical parameters are listed in Table 4. In most cases, deviations of calculated parameters from the experimental are rather small and probably due to crystal packing effects.

Experimental and calculated IR bands are listed in Table 5. Experimental and simulated IR spectra are shown in Figures S5 and S6. As one can see form Table 5 and Figures S5 and S6, calculated vibration frequencies are in good agreement with experimental values and can thus be used for band assignments. In the spectrum of the ligand, bands at 1520 and $1437 \mathrm{~cm}^{-1}$ were associated with asymmetrical pyrazole 
ring stretching vibrations, while the band at $1311 \mathrm{~cm}^{-1}$ corresponded to symmetrical pyrazole stretching vibrations. Upon coordination to copper(II), one of the pyrazole stretching bands shifted to a lower frequency region (1404 and $\left.1405 \mathrm{~cm}^{-1}\right)$, while two others remained at essentially the same positions. Bands of in-plane $\mathrm{C}-\mathrm{H}$ vibrations $(\beta \mathrm{CH})$ also underwent a coordination-induced low-frequency shift. It is interesting to note that the band assigned to aliphatic $\mathrm{CCH}$ bending vibrations demonstrated a considerable high-frequency shift from 1293 to $1471 \mathrm{~cm}^{-1}$, which can be associated with the change of molecular symmetry that takes place upon coordination. Low-frequency bands at 254 and $260 \mathrm{~cm}^{-1}$ in the spectra of complexes $\mathbf{1}$ and $\mathbf{2}$ were assigned to $\mathrm{Cu}-\mathrm{Cl}$ stretching vibrations.

Table 4. Calculated and experimental geometrical parameters of $\mathrm{Pz}^{4}$ and complexes.

\begin{tabular}{cccccc}
\hline Parameter & Experimental & Calculated & Parameter & Experimental & Calculated \\
\hline & Pz $^{4}$ & & & Complex 1 & \\
\hline $\mathrm{d}(\mathrm{C} 7-\mathrm{N} 3), \AA$ & $1.450(1)$ & 1.452 & $\mathrm{~d}(\mathrm{Cu} 1-\mathrm{Cl} 1), \AA$ & $2.436(1)$ & 2.426 \\
$\mathrm{~d}(\mathrm{~N} 3-\mathrm{N} 4), \AA$ & $1.355(1)$ & 1.359 & $\mathrm{~d}(\mathrm{Cu} 1-\mathrm{Cl} 2), \AA$ & $2.314(1)$ & 2.323 \\
$\mathrm{~d}(\mathrm{~N} 4-\mathrm{C} 4), \AA$ & $1.329(2)$ & 1.330 & $\mathrm{~d}(\mathrm{Cu} 1-\mathrm{O} 1), \AA$ & $1.940(3)$ & 2.012 \\
$\mathrm{~d}(\mathrm{C} 4-\mathrm{C} 5), \AA$ & $1.392(2)$ & 1.416 & $\mathrm{~d}(\mathrm{Cu} 1-\mathrm{N} 1), \AA$ & $2.074(3)$ & 2.212 \\
$\mathrm{~d}(\mathrm{C} 5-\mathrm{C} 6), \AA$ & $1.368(2)$ & 1.380 & $\mathrm{~d}(\mathrm{Cu} 1-\mathrm{N} 3), \AA$ & $2.009(3)$ & 2.067 \\
$\mathrm{~d}(\mathrm{C} 6-\mathrm{N} 3), \AA$ & $1.357(1)$ & 1.366 & $\mathrm{~d}(\mathrm{~S} 1=\mathrm{O} 1), \AA$ & $1.533(2)$ & 1.556 \\
$\mathrm{~d}\left(\mathrm{C} 7-\mathrm{C} 7^{\prime}\right), \AA$ & $1.541(1)$ & 1.558 & $\mathrm{~d}(\mathrm{~N} 3-\mathrm{N} 4), \AA$ & $1.363(3)$ & 1.365 \\
& & $\mathrm{~d}\left(\mathrm{C} 7-\mathrm{C} 7^{\prime}\right), \AA$ & $1.551(3)$ & 1.564 \\
& & $\varphi(\mathrm{O} 1-\mathrm{Cu} 1-\mathrm{N} 3),{ }^{\circ}$ & $171.7(1)$ & 168.7 \\
& & $\varphi(\mathrm{O} 1-\mathrm{Cu} 1-\mathrm{N} 1),{ }^{\circ}$ & $83.7(1)$ & 83.4 \\
& & $\varphi(\mathrm{O} 1-\mathrm{Cu} 1-\mathrm{Cl} 2),{ }^{\circ}$ & $94.09(9)$ & 90.3 \\
& & $\varphi(\mathrm{Cl}-\mathrm{Cu} 1-\mathrm{Cl}),{ }^{\circ}$ & $116.67(3)$ & 126.0 \\
\hline
\end{tabular}

Table 5. Calculated (scaled) and experimental vibration frequencies for $\mathrm{Pz}^{4}$ and complex.

\begin{tabular}{|c|c|c|c|c|c|}
\hline \multirow[b]{2}{*}{ Vibration } & \multicolumn{2}{|c|}{$\mathrm{Pz}^{4}$} & \multicolumn{3}{|c|}{$\left[\mathrm{Cu}_{2}\left(\mathrm{Pz}^{4}\right)(\mathrm{DMSO})_{2} \mathrm{Cl}_{4}\right]$} \\
\hline & $\tilde{v}$ calc., $\mathrm{cm}^{-1}$ & $\tilde{v} \exp ., \mathrm{cm}^{-1}$ & $\begin{array}{c}\tilde{v} \text { calc., } \mathrm{cm}^{-1} \\
1\end{array}$ & $\begin{array}{c}\tilde{v} \exp ., \mathrm{cm}^{-1} \\
1\end{array}$ & $\begin{array}{c}\tilde{v} \exp ., \mathrm{cm}^{-1} \\
2\end{array}$ \\
\hline$v \mathrm{CH}(\mathrm{Pz})$ & 3173 & 3137 & 3139 & 3125 & 3128 \\
\hline$v \mathrm{CH}(\mathrm{Pz})$ & 3156 & 3130 & - & - & - \\
\hline vCH $(\mathrm{Pz})$ & 3142 & 3115 & - & - & - \\
\hline vCH (DMSO) & - & - & 3065 & 2987 & 3000 \\
\hline$v \mathrm{CH}$ & 3054 & 3018 & 2952 & 2946 & 2943 \\
\hline$v \mathrm{CH}$ & 3042 & 2994 & - & - & - \\
\hline$v P z_{\text {asym }}$ & 1509 & 1520 & 1509 & 1513 & 1513 \\
\hline$\delta \mathrm{CCH}$ & - & - & 1458 & 1471 & 1469 \\
\hline$v P z_{\text {asym }}$ & 1420 & 1437 & 1400 & 1404 & 1405 \\
\hline$v P z_{\text {sym }}$ & 1292 & 1311 & 1291 & 1304 & 1302 \\
\hline$\beta \mathrm{CH}(\mathrm{Pz})$ & 1380 & 1391 & 1240 & 1251 & 1254 \\
\hline$\beta C H(P z)$ & 1203 & 1216 & 1192 & 1199 & 1200 \\
\hline$\beta \mathrm{CH}(\mathrm{Pz})$ & 1154 & 1172 & 1086 & 1095 & 1095 \\
\hline$\beta \mathrm{CH}(\mathrm{Pz})$ & 1073 & 1092 & 1078 & 1067 & 1068 \\
\hline$\beta \mathrm{CH}(\mathrm{Pz})$ & 1029 & 1053 & 1048 & 1035 & 1032 \\
\hline$\beta \mathrm{CH}(\mathrm{Pz})$ & 947 & 968 & - & - & - \\
\hline$\delta \mathrm{CCH}$ & 1273 & 1293 & - & - & - \\
\hline$\beta \mathrm{CH}(\mathrm{Pz})$ & 899 & 918 & - & - & - \\
\hline$\gamma \mathrm{CH}$ & 859 & 890 & - & - & - \\
\hline$\gamma \mathrm{CH}$ & 812 & 857 & - & - & - \\
\hline$\gamma \mathrm{CH}$ & 740 & 771 & 747 & 769 & 768 \\
\hline$\gamma \mathrm{CH}$ & 725 & 754 & - & - & - \\
\hline$\delta \mathrm{NCH}$ & 759 & 783 & 768 & 780 & 789 \\
\hline vSO (DMSO) & - & - & 1003 & 988 & 991 \\
\hline vSO (DMSO) & - & - & 899 & 944 & 944 \\
\hline$\gamma \mathrm{CH}$ & 606 & 616 & 603 & 610 & 612 \\
\hline$\delta \mathrm{CCH}$ & 569 & 585 & 548 & 550 & 549 \\
\hline$\delta \mathrm{NCC}$ & 348 & 357 & - & - & - \\
\hline$\delta \mathrm{NCC}$ & 302 & 319 & - & - & - \\
\hline$\delta \mathrm{NCC}$ & 230 & 245 & - & - & - \\
\hline$\delta \mathrm{NCC}$ & 106 & 134 & - & - & - \\
\hline$v \mathrm{Cu}-\mathrm{Cl}$ & - & - & 244 & 254 & 260 \\
\hline
\end{tabular}

Abbreviations: $v \mathrm{CH}(\mathrm{Pz}$ - - stretching vibrations of $\mathrm{C}-\mathrm{H}$ bonds in pyrazole rings; $v \mathrm{CH}$ (DMSO)—stretching vibrations of $\mathrm{C}-\mathrm{H}$ bonds in DMSO molecules; $v \mathrm{CH}$-stretching vibrations of aliphatic $\mathrm{C}-\mathrm{H}$ bonds; $v_{\mathrm{Pz}}$ asym, $v \mathrm{Pz}_{\mathrm{sym}}$ - asymmetrical and symmetrical pyrazole ring stretching vibrations; $\delta \mathrm{CCH}$-bending vibrations of aliphatic $\mathrm{C}-\mathrm{C}-\mathrm{H}$ bonds; $\beta \mathrm{CH}(\mathrm{Pz})$-in-plane bending vibrations of $\mathrm{C}-\mathrm{H}$ bonds in pyrazole rings; $\gamma \mathrm{CH}$-out-of-plane bending vibrations of $\mathrm{C}-\mathrm{H}$ bonds in pyrazole rings; $\delta \mathrm{NCH}-$ bending vibrations of aliphatic $\mathrm{N}-\mathrm{C}-\mathrm{H}$ bonds; $v \mathrm{SO}$ (DMSO) - stretching vibrations of S=O bonds in DMSO molecules; $8 \mathrm{NCC}$ - bending vibrations of aliphatic N-C $-\mathrm{C}$ bonds; $\mathrm{v} \mathrm{Cu}-\mathrm{Cl}-$ stretching vibrations of $\mathrm{Cu}-\mathrm{Cl}$ bonds. 


\subsection{Thermal and XRD Analyses}

The curves of thermal analysis for compounds $\mathbf{1}$ and $\mathbf{2}$ are shown in Figure 5. Investigation of thermal properties in helium atmosphere revealed that the first step of thermolysis for both compounds is associated with the removal of solvated molecules in the range of $40-150^{\circ} \mathrm{C}$ for $\mathbf{1}$ and $100-200^{\circ} \mathrm{C}$ for $\mathbf{2}$. The XRD pattern for thermolysis products of 1 at $150{ }^{\circ} \mathrm{C}$ differs from the pattern of the initial compound (Figure 6), suggesting a structural rearrangement. Further decomposition leads to formation of $\mathrm{Cu}$ and $\mathrm{CuCl}$ and amorphous products of ligand degradation at $350^{\circ} \mathrm{C}$, and the final step corresponds to partial sublimation of $\mathrm{CuCl}$ and formation of amorphous carbon. Formation of cubic $\mathrm{CuCl}$ and copper phases at thermolysis temperature $350{ }^{\circ} \mathrm{C}$ was observed previously [48].

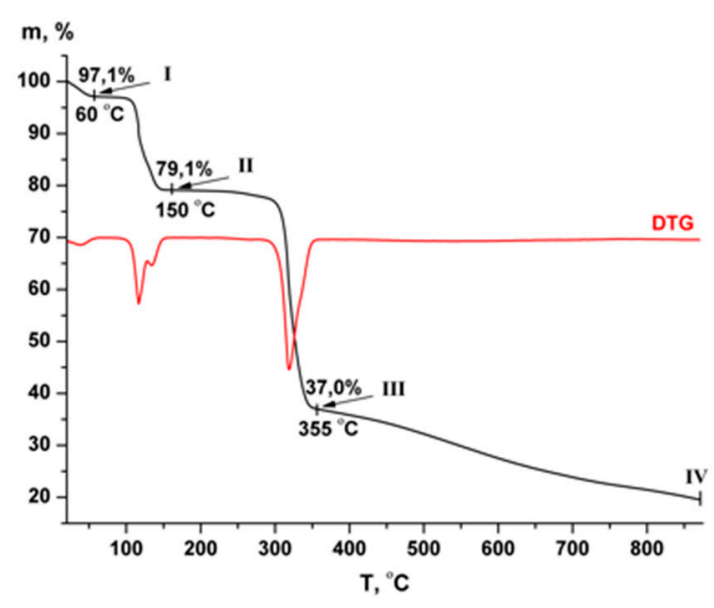

(a)

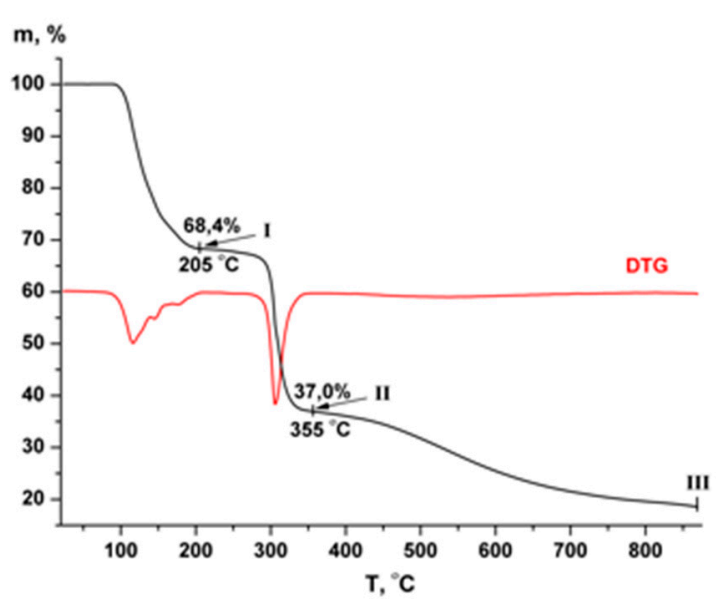

(b)

Figure 5. TG curves of $\mathbf{1}(\mathbf{a})$ and $\mathbf{2}(\mathbf{b})$ in inert atmosphere at $10 \mathrm{~K} / \mathrm{min}$ speed rate.

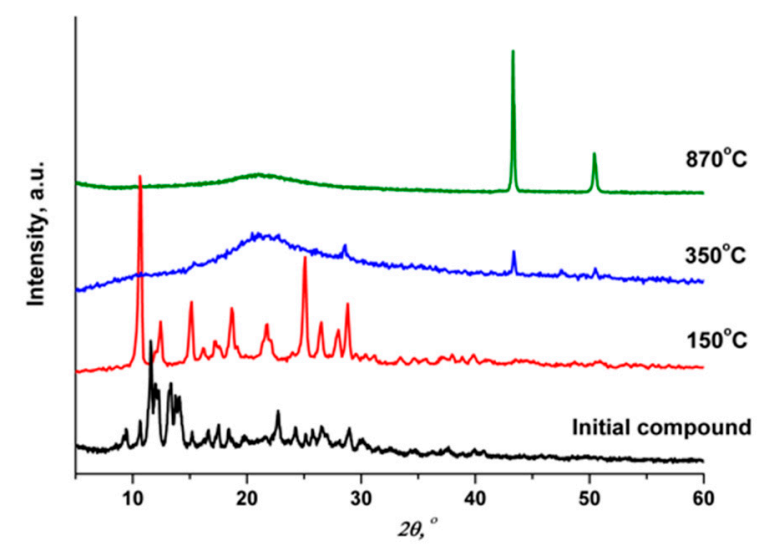

(a)

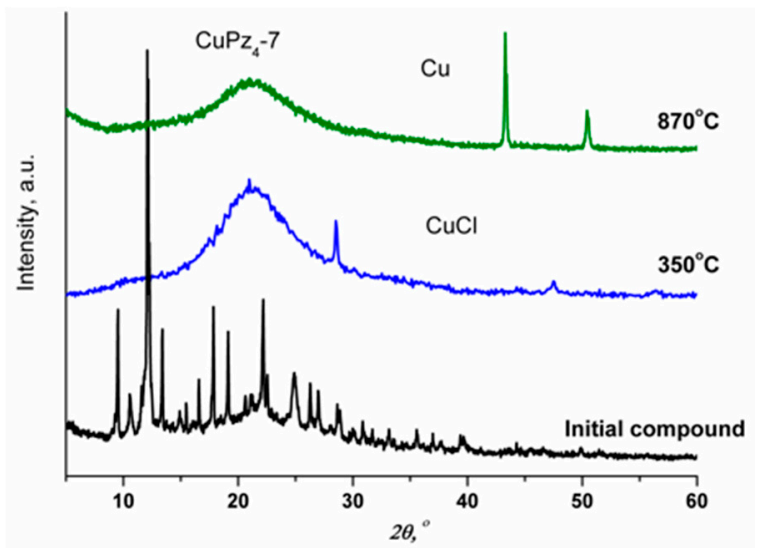

(b)

Figure 6. The XRD patterns for thermolysis products of complexes $\mathbf{1}(\mathbf{a})$ and $\mathbf{2}(\mathbf{b})$.

It should be noted that dehydration process of 1 proceeds in two separate steps, and it is thus possible to obtain an anhydrous compound with composition $\left[\mathrm{Cu}_{2}\left(\mathrm{Pz}^{4}\right)(\mathrm{DMSO})_{2} \mathrm{Cl}_{4}\right]$. Thermal decomposition of 2 runs in a more complex manner with a simultaneous loss of outer- and inner-sphere dimethyl sulfoxide molecules in one step (Figure 5). Concurrent loss of both outer- and inner-sphere DMSO molecules can be explained by the absence of intermolecular interactions between solvent molecules in complex $\mathbf{2}$ in contrast to the hydrogen-bonded network in complex $\mathbf{1}$. 


\section{Conclusions}

Two binuclear coordination compounds of $\mathrm{Cu}$ (II) chloride with 1,1,2,2-tetrakis(pyrazol-1-yl)ethane $\left(\mathrm{Pz}^{4}\right)$ of the composition $\left[\mathrm{Cu}_{2}\left(\mu_{2}-\mathrm{Pz}^{4}\right)(\mathrm{DMSO})_{2} \mathrm{Cl}_{4}\right] \cdot 4 \mathrm{H}_{2} \mathrm{O}$ and $\left[\mathrm{Cu}_{2}\left(\mu_{2}-\mathrm{Pz}^{4}\right)(\mathrm{DMSO})_{2} \mathrm{Cl}_{4}\right] \cdot 2 \mathrm{DMSO}$ have been synthesized and fully characterized by elemental analysis, IR spectroscopy, thermogravimetric analysis, single-crystal X-ray diffraction, and powder diffraction analysis. Crystal structure analysis of the compound $\left[\mathrm{Cu}_{2}\left(\mu_{2}-\mathrm{Pz}^{4}\right)(\mathrm{DMSO})_{2} \mathrm{Cl}_{4}\right] \cdot 4 \mathrm{H}_{2} \mathrm{O}$ revealed a layered supramolecular structure formed by $\mathrm{OH} \cdots \mathrm{Cl}$ and $\mathrm{OH} \cdots \mathrm{O}$ (dashed red lines) hydrogen bonds.

Supplementary Materials: The following are available online at http://www.mdpi.com/2073-4352/9/4/222/s1, Table S1: Atomic coordinates for optimized geometry of complex 1, Table S2: Atomic coordinates for optimized geometry of ligand $\mathrm{Pz}^{4}$, Figure S1: Overlay of the metallocycles of $\mathbf{1}$ and $\mathbf{2},\left[\mathrm{Cu}_{2}\left(\mathrm{Pz}^{4}\right)\left(\mathrm{H}_{2} \mathrm{O}\right)_{2}\left(\mathrm{NO}_{3}\right)_{4}\right]$ (refcode XUDWUQ), $\left[\left\{\mathrm{Cu}\left(\mathrm{Pz}^{4}\right)\left(\mathrm{H}_{2} \mathrm{O}\right)\left(\mathrm{NO}_{3}\right)_{2}\right\}_{2}\right]_{n}$ (refcode PUZSAG), $\left[\mathrm{Cu}\left(\mathrm{Pz}^{4}\right)\left(\mathrm{NO}_{3}\right)_{2}\right]_{\mathrm{n}}$ (refcode PUZSEK) and $\left[\mathrm{Cu}_{2}\left(\mathrm{Pz}^{4}\right)\left(\mathrm{H}_{2} \mathrm{O}\right)_{2}\left(\mathrm{NO}_{3}\right)_{4}\right]$ (refcode XUDWUQ01), Figure S2: Overlay of the molecules 1 and 2, Figure S3: The $\mathrm{d}_{\text {norm }}$ Hirshfeld surface of the molecules 1 and 2 showing intermolecular $\mathrm{C}-\mathrm{H} \cdots \mathrm{D}$ and $\mathrm{O}-\mathrm{H} \cdots \mathrm{D}(\mathrm{D}=\mathrm{Cl}, \mathrm{O})$ contacts, Figure S4: Crystal packing of $\mathbf{1}$ and $\mathbf{2}$ with a view along the chains built from the molecules, Figure S5: Calculated and experimental IR spectra of the ligand $\mathrm{Pz}^{4}$ in the characteristic $1600-500 \mathrm{~cm}^{-1}$ range, Figure S6: Calculated and experimental IR spectra of compound 1 in the characteristic 1600-500 $\mathrm{cm}^{-1}$ range. CCDC 1900906-1900908 contain the supplementary crystallographic data for this paper. These data can be obtained free of charge from the Cambridge Crystallographic Data Centre via www.ccdc.cam.ac.uk/data_request/cif.

Author Contributions: Conceptualization, A.P.; investigation, E.L., T.S., A.S., E.S. and E.F.; writing-original draft, E.L., T.S., and E.S.; writing-review and editing, A.P.

Funding: The reported study was supported by the Russian Science Foundation (Project No. 18-73-00294).

Acknowledgments: DTF calculations were carried within the framework of the Tomsk Polytechnic University Competitiveness Enhancement Program. The authors are thankful to Dr. Enrico Benassi for assistance with DFT calculations.

Conflicts of Interest: The authors declare no conflict of interests.

\section{References}

1. Kharisov, B.I.; Elizondo Perla, M.; Jiménez-Pérez, V.M.; Kharissova, O.V.; Nájera Martínez, B.; Pérez, N. Recent advances on ditopic ligands. J. Coord. Chem. 2010, 63, 1-25. [CrossRef]

2. Stock, N.; Biswas, S. Synthesis of metal-organic frameworks (MOFs): Routes to various MOF topologies, morphologies, and composites. Chem. Rev. 2012, 112, 933-969. [CrossRef] [PubMed]

3. Northrop, B.H.; Yang, H.-B.; Stang, P.J. Coordination-driven self-assembly of functionalized supramolecular metallacycles. Chem. Commun. 2008, 5896-5908. [CrossRef]

4. Lu, W.; Wei, Z.; Gu, Z.-Y.; Liu, T.-F.; Park, J.; Park, J.; Tian, J.; Zhang, M.; Zhang, Q.; Gentle III, T.; et al. Tuning the structure and function of metal-organic frameworks via linker design. Chem. Soc. Rev. 2014, 43, 5561-5593. [CrossRef] [PubMed]

5. Moulton, B.; Zaworotko, M.J. From molecules to crystal engineering: Supramolecular Isomerism and Polymorphism in Network Solids. Chem. Rev. 2001, 101, 1629-1658. [CrossRef]

6. Gu, J.; Wen, M.; Cai, Y.; Shi, Z.; Arol, A.S.; Kirillova, M.V.; Kirillov, A.M. Metal-Organic Architectures Assembled from Multifunctional Polycarboxylates: Hydrothermal Self-Assembly, Structures, and Catalytic Activity in Alkane Oxidation. Inorg. Chem. 2019, 58, 2403-2412. [CrossRef]

7. Gu, J.; Cai, Y.; Wen, M.; Ge, Z.; Kirillov, M.A. New Topologically Unique Metal-Organic Architectures Driven by a Pyridine-Tricarboxylate Building Block. Crystal 2018, 8, 353. [CrossRef]

8. Lai, Q.; Paskevicius, M.; Sheppard, D.A.; Buckley, C.E.; Thornton, A.W.; Hill, M.R.; Gu, Q.; Mao, J.; Huang, Z.; Liu, H.K.; et al. Hydrogen Storage Materials for Mobile and Stationary Applications: Current State of the Art. ChemSusChem 2015, 8, 2789-2825. [CrossRef]

9. Pettinari, C.; Tăbăcaru, A.; Galli, S. Coordination Polymers and Metal-Organic Frameworks Based on Poly(pyrazole)-containing Ligands. Coord. Chem. Rev. 2016, 307, 1-31. [CrossRef]

10. Pettinari, C.; Marchetti, F.; Mosca, N.; Tosi, G.; Drozdov, A. Application of metal-organic frameworks. Polym. Int. 2017, 66, 731-744. [CrossRef]

11. Adatoz, E.; Avci, A.K.; Keskin, S. Opportunities and challenges of MOF-based membranes in gas separations. Sep. Purif. Technol. 2015, 152, 207-237. [CrossRef] 
12. Wang, L.; Han, Y.; Feng, X.; Zhou, J.; Qi, P.; Wang, B. Metal-organic frameworks for energy storage: Batteries and supercapacitors. Coord. Chem. Rev. 2015, 307, 361-381. [CrossRef]

13. Kreno, L.E.; Leong, K.; Farha, O.K.; Allendorf, M.; Van Duyne, R.P.; Hupp, J.T. Metal-organic framework materials as chemical sensors. Chem. Rev. 2012,112, 1105-1125. [CrossRef]

14. Zhang, L.; Kang, Z.; Xin, X.; Sun, D. Metal-organic frameworks based luminescent materials for nitroaromatics sensing. CrystEngComm 2016, 18, 193-206. [CrossRef]

15. Zheng, H.; Xing, L.; Cao, Y.; Che, S. Coordination bonding based pH-responsive drug delivery systems. Coord. Chem. Rev. 2013, 257, 1933-1944. [CrossRef]

16. Cai, W.; Chu, C.-C.; Liu, G.; Wáng, Y.-X.J. Metal-Organic Framework-Based Nanomedicine Platforms for Drug Delivery and Molecular Imaging. Small 2015, 11, 4806-4822. [CrossRef] [PubMed]

17. Zavakhina, M.S.; Khan, I.S.; Barsukova, M.O.; Sapianik, A.A.; Samsonenko, D.G.; Dybtsev, D.N.; Fedin, V.P. Chiral guest in a chiral framework: X-ray diffraction study. Russ. Chem. Bull. 2018, 67, 1268-1272. [CrossRef]

18. Corma, A.; García, H.; Llabrés i Xamena, F.X. Engineering metal organic frameworks for heterogeneous catalysis. Chem. Rev. 2010, 110, 4606-4655. [CrossRef] [PubMed]

19. Zhao, N.; Li, Y.; Gu, J.; Fernandes, T.A.; Kirillova, M.V.; Kirillov, A.M. New Copper(II) Coordination Compounds Assembled from Multifunctional Pyridine-Carboxylate Blocks: Synthesis, Structures, and Catalytic Activity in Cycloalkane Oxidation. Molecules 2018, 24, 6. [CrossRef]

20. Beheshti, A.; Zafarian, H.R.; Abrahams, C.T.; Bruno, G.; Rudbari, H.A. Investigating the effect of anion substitutions on the structure of silver-based coordination polymers. Inorg. Chim. Acta 2015, 438, 196-202. [CrossRef]

21. Gardinier, J.R.; Tatlock, H.M.; Hewage, J.S.; Lindeman, S.V. Cyclic versus Polymeric Supramolecular Architectures in Metal Complexes of Dinucleating Ligands: Silver(I) Trifluoromethanesulfonate Complexes of the Isomers of Bis(di(1H-pyrazolyl)methyl)-1,1'-biphenyl. Cryst. Growth Des. 2013, 13, 3864-3877. [CrossRef]

22. Reger, D.L.; Foley, E.A.; Smith, M.D. Synthesis of a tritopic, third-generation bis(1-pyrazolyl)methane ligand and its silver(I) complex: Unexpected structure with high coordination numbers. Inorg. Chem. Commun. 2010, 13, 568-572. [CrossRef]

23. Morin, T.J.; Merkel, A.; Lindeman, S.V.; Gardinier, J.R. Breaking the Cycle: Impact of Sterically-Tailored Tetra(pyrazolyl)lutidines on the Self-Assembly of Silver(I) Complexes. Inorg. Chem. 2010, 49, 7992-8002. [CrossRef]

24. Wang, S.; Zang, H.; Sun, C.; Xu, G.; Wang, X.; Shao, K.; Lan, Y.; Su, Z. Anion-directed genuine meso-helical supramolecular isomers of two 1D Ag(i) complexes based on arene-linked bis(pyrazolyl)methane ligands. CrystEngComm 2010, 12, 3458-3462. [CrossRef]

25. Reger, D.L.; Watson, R.P.; Smith, M.D. Silver(I) complexes of fixed, polytopic bis(pyrazolyl)methane ligands: Influence of ligand geometry on the formation of discrete metallacycles and coordination polymers. Inorg. Chem. 2006, 45, 10077-10087. [CrossRef] [PubMed]

26. Reger, D.L.; Watson, R.P.; Gardinier, J.R.; Smith, M.D. Impact of Variations in Design of Flexible Bitopic Bis(pyrazolyl)methane Ligands and Counterions on the Structures of Silver(I) Complexes: Dominance of Cyclic Dimeric Architecture. Inorg. Chem. 2004, 43, 6609-6619. [CrossRef] [PubMed]

27. Reger, D.L.; Gardinier, J.R.; Christian Grattan, T.; Smith, M.R.; Smith, M.D. Synthesis of the silver(I) complex of $\mathrm{CH}_{2}\left[\mathrm{CH}\left(\mathrm{pz}^{4 \mathrm{Et}}\right)_{2}\right]_{2}$ containing the unprecedented $\left[\mathrm{Ag}\left(\mathrm{NO}_{3}\right)_{4}\right]^{3-}$ anion: A general method for the preparation of 4-(alkyl). New J. Chem. 2003, 27, 1670-1677. [CrossRef]

28. Reger, D.L.; Semeniuc, R.F.; Silaghi-Dumitrescu, I.; Smith, M.D. Influences of Changes in Multitopic Tris(pyrazolyl)methane Ligand Topology on Silver(I) Supramolecular Structures. Inorg. Chem. 2003, 42, 3751-3764. [CrossRef] [PubMed]

29. Semitut, E.; Komarov, V.; Sukhikh, T.; Filatov, E.; Potapov, A. Synthesis, Crystal Structure and Thermal Stability of 1D Linear Silver(I) Coordination Polymers with 1,1,2,2-Tetra(pyrazol-1-yl)ethane. Crystals 2016, 6, 138. [CrossRef]

30. Potapov, A.S.; Nudnova, E.A.; Khlebnikov, A.I.; Ogorodnikov, V.D.; Petrenko, T.V. Synthesis, crystal structure and electrocatalytic activity of discrete and polymeric copper(II) complexes with bitopic bis(pyrazol-1-yl) methane ligands. Inorg. Chem. Commun. 2015, 53, 72-75. [CrossRef] 
31. Semitut, E.Y.; Komarov, V.Y.; Filatov, E.Y.; Kuznetsova, A.S.; Khlebnikov, A.I.; Potapov, A.S. Synthesis and structural characterization of copper(II) coordination polymers with 1,1,2,2-tetra(pyrazol-1-yl)ethane. Inorg. Chem. Commun. 2016, 64, 23-26. [CrossRef]

32. Dehury, N.; Maity, N.; Tripathy, S.K.; Basset, J.-M.; Patra, S. Dinuclear Tetrapyrazolyl Palladium Complexes Exhibiting Facile Tandem Transfer Hydrogenation/Suzuki Coupling Reaction of Fluoroarylketone. ACS Catal. 2016, 6, 5535-5540. [CrossRef]

33. Wang, J.-X.; Zhu, Z.-R.; Bai, F.-Y.; Wang, X.-Y.; Zhang, X.-X.; Xing, Y.-H. Molecular design and the optimum synthetic route of the compounds with multi-pyrazole and its derivatives and the potential application in antibacterial agents. Polyhedron 2015, 99, 59-70. [CrossRef]

34. Kraus, W.; Nolze, G. PowderCell 2.4; Program for the representation and manipulation of crystal structures and calculation of the resulting X-ray powder patterns; Federal Institute for Materials Research and Testing: Berlin, Germany, 2000.

35. International Centre for Diffraction Data (ICDD). PDF-2 Release; ICDD: Swarthmore, PA, USA, 2014.

36. PEX2, Version 2.0; SAINT, Version 8.18c; SADABS, Version 2.11; Bruker Advanced X-ray Solutions, Bruker AXS Inc.: Madison, WI, USA, 2000-2012.

37. Sheldrick, G.M. Crystal structure refinement with SHELXL. Acta Crystallogr. Sect. C 2015, 71, 3-8. [CrossRef]

38. Dolomanov, O.V.; Bourhis, L.J.; Gildea, R.J.; Howard, J.A.K.; Puschmann, H. OLEX2: A complete structure solution, refinement and analysis program. J. Appl. Crystallogr. 2009, 42, 339-341. [CrossRef]

39. Becke, A.D. Density-functional exchange-energy approximation with correct asymptotic behavior. Phys. Rev. A 1988, 38, 3098-3100. [CrossRef]

40. Lee, C.; Yang, W.; Parr, R.G. Development of the Colle-Salvetti correlation-energy formula into a functional of the electron density. Phys. Rev. B 1988, 37, 785-789. [CrossRef]

41. Vosko, S.H.; Wilk, L.; Nusair, M. Accurate spin-dependent electron liquid correlation energies for local spin density calculations: A critical analysis. Can. J. Phys. 1980, 58, 1200-1211. [CrossRef]

42. Stephens, P.J.; Devlin, F.J.; Chabalowski, C.F.; Frisch, M.J. Ab Initio Calculation of Vibrational Absorption and Circular Dichroism Spectra Using Density Functional Force Fields. J. Phys. Chem. 1994, 98, 11623-11627. [CrossRef]

43. Ditchfield, R. Self-Consistent Molecular-Orbital Methods. IX. An Extended Gaussian-Type Basis for Molecular-Orbital Studies of Organic Molecules. J. Chem. Phys. 1971, 54, 724. [CrossRef]

44. Frisch, M.J.; Trucks, G.W.; Schlegel, H.B.; Scuseria, G.E.; Robb, M.A.; Cheeseman, J.R.; Scalmani, G.; Barone, V.; Mennucci, B.; Petersson, G.A.; et al. Gaussian 09; revision D.01; Gaussian, Inc.: Wallingford, CT, USA, 2013.

45. Turner, M.J.; McKinnon, J.J.; Wolff, S.K.; Grimwood, D.J.; Spackman, P.R.; Jayatilaka, D.; Spackman, M.A. CrystalExplorer17; University of Western Australia: Perth, Australia, 2017.

46. Potapov, A.S.; Nudnova, E.A.; Khlebnikov, A.I.; Ogorodnikov, V.D.; Petrenko, T.V. Synthesis of new polydentate pyrazolyl-ethene ligands by interaction of 1H-pyrazole and 1,1,2,2-tetrabromoethane in a superbasic medium. J. Heterocycl. Chem. 2011, 48, 645-651. [CrossRef]

47. Addison, A.W.; Rao, T.N.; Reedijk, J.; van Rijn, J.; Verschoor, G.C. Synthesis, structure, and spectroscopic properties of copper(II) compounds containing nitrogen-sulphur donor ligands; the crystal and molecular structure of aqua[1,7-bis( $N$-methylbenzimidazol-2[prime or minute]-yl)-2,6-dithiaheptane]copper(II) perchlorate. J. Chem. Soc. Dalt. Trans. 1984, 1349-1356. [CrossRef]

48. Martynova, S.A.; Filatov, E.Y.; Korenev, S.V.; Kuratieva, N.V.; Sheludyakova, L.A.; Plusnin, P.E.; Shubin, Y.V.; Slavinskaya, E.M.; Boronin, A.I. Low temperature synthesis of $\mathrm{Ru}-\mathrm{Cu}$ alloy nanoparticles with the compositions in the miscibility gap. J. Solid State Chem. 2014, 212, 42-47. [CrossRef]

(C) 2019 by the authors. Licensee MDPI, Basel, Switzerland. This article is an open access article distributed under the terms and conditions of the Creative Commons Attribution (CC BY) license (http://creativecommons.org/licenses/by/4.0/). 